\title{
The relationship between Constitution, International Treaties and Contracts
}

\section{Véra Jacob de Fradera ${ }^{1}$ Professor at the Federal University of Rio Grande do Sul, BRAZIL.}

This subject concerns the important transformations occurred on the brazilian Private Law due to two main reasons: first, the constitutionalization or publicization of the private law; second, the massification of consumer reports and the not equitable economic conditions between consumers and sellers.

As it is known, on one hand, on almost all Romano-Germanic systems, people's private life is governed by old Civil Codes, which contain rules that are not adequate to our societies, which changed in a social, economic, legal and moral point of view;

On the other hand, we assert the existence of many recent Constitutions in those systems. This fact produces a necessary modernization of the Civil Codes, because Constitution rules are more up to date, more flexible and for these reasons, they produce a sort of stream of fresh air in the old Civil Codes.

Thus, we face a true refreshing of the Family Law, of the Property Law and the Contract Law.

In turn, the influence of the Constitution of 1988 in the Private Law was also overwhelming, so that some jurists believe it to be the current center of the legal system, and not the Civil Code anymore. ${ }^{2}$

We face, therefore, a true disruption of the private law system, being difficult to establish a sole center of irradiation of solutions for the problems related to the individual in its private activity, as the three sets of rules, the Civil Code, the Consumer Code and the Federal Constitution, influence ones to the others. ${ }^{3}$

This paper was presented originally, as a report, on the 16th International Congress of Comparative Law - Brisbane, July 2002

2 This is a school of Italian origin, being Professor Pietro PERLINGIERI, one of its exponents. Amongst its Brazilian disciples the distinguished Professors Gustavo TEPEDINO, and Maria Celina Bodin de MORAES, of the UERJ.

${ }^{3}$ On this matter, see the classic study of N. IRTI, "L 'età della decodificazione", Milano, Giuffrè, 1976. 
The Codes, so remarked by jurists of the past and still by many in our country, had produced some harm, as, for example, the "positivism", disease still not totally eradicated between us. Not that Codes and "positivism" are essentially bound, but it can be said that Codes have leaned jurists to develop a certain exaggeration in their affection towards the statutes. $^{4}$

Another phenomenon influences the Law in general and, specifically with regard to contracts, produces significant modifications, altering the form of the relationship between the parties: the importance and the presence of the economic phenomenon in the contractual sphere are so great that they modify substantially some of the aspects of the contract. The economic contract notion coexists with the classic civilistic notion.

It is also necessary to mention the globalization of trade, which operates transformations in national, international and transnational levels, as the regionalization of the markets is another characteristic of our time.

The formation of Free Trade Areas generates a revision of the national and international contract concepts to create one third category, the transnational one, regulated either by a conventional international norm, or a principial norm,like the Principles UNIDROIT for International Commercial Contracts, elected by the parties as a binding rule of the contract or, for certain effects, by the Classic International Private Law. ${ }^{5}$

Indeed interesting and instigating aspect for a Law professional is the fact that these spheres, national, international and transnational, interpenetrate each other, producing a new contract concept, a hybrid class. Thus, some solutions imitated from the international contract are present in the national contract, for example, the adoption of the Hardship clause ${ }^{6}$ and the Renegotiation clause; products of the International praxis, in national contracts.

Another interesting example is the Vienna Convention of 1980 on International Sales of Goods, in force in many countries. The systematic of the C.I.S.G. modifies essential aspects of the contract, for instance, when it foresees the sale without price, which turned out to be admitted in law systems traditionally against substantial changes. ${ }^{7}$ Some of the principles included by the legislator in the Convention are influencing the domestic contract law in certain countries, especially in those where a unification of the

\footnotetext{
${ }^{4}$ On this subject, see Revue Droits, numbers 25, 26 and 27, PUF, Paris; on the domestic law, the excellent study of Fábio Siebeneichler de ANDRADE, "Da Codificação, crônica de um conceito", Livraria do Advogado, Porto Alegre, 1997.

5 The European Union has not already satisfactorily solved the question related to the different contract conceptions effective in the national systems. In the Roman-Germanic family itself, there are difficulties in approximating the French and the German Laws. The existence of the Common Law system makes the problematic even more difficult.

${ }^{6}$ In the sense of "difficulty". The origin of this clause is customary, being admissible its insertion in contracts of long duration, usually those from which the performance consists of the supply of energy forms: oil, gas, electricity, etc. The hardship clause is so practical, that it has been invoked sometimes in the domestic law, despite the fact that no reference to the original denomination has been made.

${ }^{7}$ On the jurisprudential applications of the Vienna Convention of 1980 on International Sales of Goods, see the article of Professor Claude WITZ, "La Convention de Vienne sur la vente internationale of marchandises à l'épreuve de la jurisprudence naissante, Dalloz, 1995, Chron. p. 143.
} 
civil and commercial obligations already exists. Brazilian Government seems not recognize the importance of this Convention to develop the international commerce in South America. Argentina, Chile and Uruguay governments signed this Vienna Convention.

In turn, the international contract suffers permanently the influence of economic and politic factors.

Therefore, the private autonomy, in the international level, has been extraordinarily extended, creating a liberal circle in the contractual area, almost immune to the state interference, being only limited, by the already classic, Public Order and Good Customs (Bonnes Moeurs). ${ }^{8}$

Brazilian International Private Law (Introductory Law to the Civil Code) imposes the same two limits to the freedom of a person to enter private agreements with other private parties and to take unilateral legal acts. : Public Order and Good Customs, but there are some difficulties to exercise this freedom, because contract's law must be the law of the country where the contract is formed ${ }^{9}$. These norms have the same scope whether the private party proposes to act contractually or unilaterally, for the compelling nature of these norms.

These principles have the same scope and meaning regardless of whether they are applied to private party or to government conduct .

The national courts must always intervene to ensure that these constitutional limitations on party autonomy are respected. An international contract, between a Brazilian citizen and a foreign person, without observation of Public Order and Good Customs, will be avoided by the Courts. The judicial intervention occurs when the party asks for a judicial remedy for the violation of the constitutional or international rule. The kind of procedure depends on each situation and judges and Courts (State and Federal Courts) have power to enforce the limitations. However, there are no special constitutional mechanism for enforcing the relevant constitutional limitations on private autonomy.

There is non-judicial national mechanisms for insuring respect to constitutional or international limitations on party autonomy.

As it can be inferred from the already mentioned, the contract notion receives a series of influxes, of the most varied origins, being opened to the reception of multiple models. This process determines, primarily, the elaboration of a slow and gradual tendency to achieve the metanacional conception of the contractual phenomenon, leading it to a disconnection from a determined national law system and, subsequently, to have an almost international outline.

\footnotetext{
${ }^{8}$ There are several works on this subject, both in foreign and domestic literature. Between us, see Nádia de ARAÚJO, "Contratos Internacionais, Autonomia da Vontade, Mercosul e Convenções Internacionais", Ed. Renovar, 1997, RJ.

${ }^{9}$ Art. 9 of the introductory Law to the Civil Code .
} 
We finished listing a series of observations related to the Private Law, focusing our attention on the contract, which, on one hand, begins to lose its clear national character and, on the other hand, becomes nearer to a universal model.

In Brazil, Law reforms are very slowly implemented. Our country has some difficulty in customizing its legislation to meet with the requirements of the present time. This adaptation should lead to a broader consideration of the economic aspects of the contract. The reason of this reluctance probably resides in the Canonic Law, still very influent in our domestic Law.

Despite this fact, a group of jurists, in which a part of the judiciary is included, has contributed for this slow and gradual modernization, which is leisurely changing the character of the contract between us. We refer to the Comparative Law Doctrine of expression between us.

In passing, it is well known that in countries where an expressive legal tradition, parallel to the national culture, does not exist, the codification itself depends on the contribution received from the legal doctrine. Thus, in the case of Brazil and in the case of some other recent systems of mixed codification, the role played by the doctrine is essential. All aspects mentioned generate another phenomenon: the denationalization of contracts, which is accelerated by the vast influence of the comparative law doctrine in the general legal conceptions.

The contract also suffers the incidence of another considerably relevant factor: the period the humanity is nowadays going through, stipulated to be called "postmodernism".

Amongst others of its aspects, post-modernism places the Human being in the center of all concerns of the science in general, of the art and of all the culture forms. This concern and attention to the Human being can be attested by the extreme importance given by the Law, as a whole, to the fundamental rights; basic rights, the rights prior to the State and above it, and always that necessary; opposable to the State, having the system of values praised by them to guide the interpretation and application of the Law.

This concern with the fundamental rights, also in the scope of contracts, protect the exercise of the contractual freedom, the equity between the parties, prohibiting the breach of the free competition, preventing the excess, expression of the proportionality principle in the contractual sphere, etc.

To evince the adoption of international outlines in the Brazilian contractual conception, we will use the example of the projection of the fundamental rights proclaimed in the International Convention on the Human's Rights, which, through its incidence in the contractual relation, in accordance with the creative and innovative interpretation of the national Courts decisions and doctrine, equated the contract notion today effective between us with the dominant conception in the western legal systems at the present time. 
Baring in mind the objective of this research, which is to show a current tendency of the contract notion in Brazil , characterized by a progressive liberation from the outlines traced by its original legal system, we will develop these two causes that, in our view, effectively contribute to generate this phenomenon.

First Part: The projection of the Fundamental Rights in the contractual relation and its consequences: the evolution for a metanacional concept of contract and its alignment to the dominant conceptions in the western legal systems.

The expression "fundamental rights" appears in the legal texts after the second half of the $20^{\text {th }}$ century; the German "Grundgesetz" of 1949 render a formal valorization of the men's rights in the modern Constitucional Law.

The French Revolution, for the first time in the Europe, defined the men's rights in its sources, in a Declaration endowed with a solemnity that endorses its political importance and symbolic value.

The Universal Declaration of the Men's and Citizen Rights is the initial milestone of a new way of defining the fundamental rights. This new form is inspired in the Natural Law, which bases a category of rights prior to the State and above it, category that the Declaration recognizes apart from the presence or not of these rights in legislative texts.

On the other hand, the Declaration is a product of a constitutional assembly, accordingly, prior to the organization of the State powers.

Since the "Declaration", Men's rights have enjoyed constitutional consecration, thanks to its solemn character, and, slowly, they had been reaching effectiveness. This effectiveness is unfolded in a normatization process, identified in its direct applicability, in relation to the individuals, and in its supremacy, in relation to the constituted powers.

Nowadays, a new reflection regarding the fundamental rights occurs, motivated by the existence of regimes against the recognition of men's rights in the second half of the $20^{\text {th }}$ century XX, which generated a reinterpretation of the bills of rights.

According to a universal tendency, this reinterpretation aimed to identify a unity in the outline of protection of the fundamental rights. This unity was found in the almost universal recognition of the principle of the human being dignity.

Aiming a broader dynamism in the assurance and effectiveness of these basic rights, the current Constitutions had proclaimed that the fundamental rights are the basis and the objective of the State.

The first qualification of the fundamental rights affirm that they constitute public subjective rights, being the individuals its bearers, and that they are exercisable against the State.

Thus, in accordance to the lesson of $\mathrm{K} . \mathrm{SCHLAICH}{ }^{10}$, the fundamental rights underlying values must irrigate the entire law system: "they are not understood anymore as mere limitations to the power of the State; they impregnate the whole legal life and had become crucial for the conception of State".

${ }_{10}$ In "Procédures et techniques de protection des droits fondamentaux", RIDC, 1981, 2, p. 334. 
An excellent question which was exhaustingly approached by the German doctrine, is the possibility of the respect to the fundamental rights to constitute a rule of compulsory observance, not only for the State "vis à vis" the individuals, but also for the individuals in their contractual relations. This question of the possibility of an individual to oppose fundamental rights to thirds, called in German "Drittwirkung", consists of the direct applicability of the fundamental rights to all legal relationships. This thesis divides the Doctrine as well as the jurisprudence: a minority praises the direct applicability of the fundamental rights to all the legal relationships, while the majority is contrary to this position.

The Courts sometimes recognizes the thesis of the direct applicability, and sometimes denies it.

Relevant for our research is the position of the Bundesverfassungsgericht, that in a 1986 decision, ruled its conception of the direct effect of the fundamental rights in the private relations:

"The fundamental rights do not directly compel the judge in his activity of solving private law litigations; however they compel him in the extent the Grundgesetz statutes, simultaneously, in the section consecrated to the fundamental rights, elements of an objective law system.

The legal content of the fundamental rights acts on a branch of the Law through dispositions that govern it directly, specially by the general clauses and other concepts that, susceptible of interpretation and integration, must be interpreted in the sense of this legal content, what we call effect of irradiation or of application to thirds of the fundamental rights"."1

Thus, the fundamental rights protect the individual in two spheres: first, against the State, and, second, in the private sphere, because they create duties for the parties. This reflexive effect is given by means of the interpretation of the general clauses ${ }^{12}$ under the system of values created by the fundamental rights.

The subject of the applicability of the fundamental rights on the private sphere and specifically in the contractual relations has produced a number of national and foreign Doctrine debates.

Part of this Doctrine supports that the applicability of the fundamental rights must be operated in a mediated form, through ordinary law, as the ordinary Legislator is the one who must adjust the generality of the constitutional rule to the specific terms of the legal relationships of private nature.

One of the strongest arguments in favor of the mediated form of application of the fundamental rights is based on the existence of a sort of conflict between principles, as, for example, the principle of equity and the principle of freedom, both incident in a contract. Thus, in this assumption, the immediate application of the principle of equity would result in the reduction of the freedom, reaching the trade.

\footnotetext{
${ }^{11}$ BverfG 23,4,1986, cit. by Claude WITZ, op. ref. p. 42.

12 Specially the ones from $\S \S 138,242$ and 826 of the $B G B$, that constitute apertures (Einbruchstellen) for the interpretation in conformity to the fundamental rights in the private law.
} 
Another part of the Doctrine, reversely, supports that the applicability of the fundamental rights to the private relations must be given immediately, founding this position in the "normative force of the Constitution"13 and in the principle of the "unit of the Legal system".

This seems to be, at least between us, the position most accepted in many States.

Surpassed, therefore, the controversial question of the mediate or immediate applicability of the fundamental rights to the private relations, remains to inquire who is subjected to this observance, if every contractual relation, with the objective to fix limits to the Private autonomy or only those where one of its bearers is in a position of hypo sufficiency, weakness, in relation to the other, such as the relation between employer and employee or the relation between supplier and consumer, as in these relations an evident disequilibrium between the co contractors occurs.

The response to this investigation is given by the Portuguese Professor, C. A. da Mota Pinto. ${ }^{14}$

According to his understanding, the incidence of the fundamental rights in the relations where hypo sufficiency of one of the parties does not exist, only could occur if and when, a violation of one of the personality rights of one of the contractors happens. We remember, as an example, the refusal to contract because of religious or racial discrimination, or a contract containing a clause forbidding one of the contractors to practice its religion.

In Brazil to enter into private agreements or contracts with other private parties, a person must observe the limits created by article 4 of the Brazilian Constitution : "Brazilian Republic considers as its fundamental aim to built a free, equitable and united society, to provide to all people the conditions to live without discriminations based on origin, race, sex, color age and any form of discrimination". It is not allowed to a party to say that she does not contract with an Asiatic person, for instance, does not accept to have a Japanese secretary, or rent a car to a Jew. Brazil has signed many Treaties about the protection of human rights. Nevertheless, there is an important article of the Constitution (art. 5 , LXXVII, § 2 ) that says : "Rights and warranties expressed at this Constitution do not exclude others, derived from the State regime and from the principles adopted by it, or from the international treaties signed by Brazilian Federative Republic".

Brazilian Courts are still a little reticent when applying the fundamental rights to the private relations, despite the great development of this subject after the advent of the Federal Constitution of $1988 .{ }^{15}$ Despite this fact, we can present a roll of decisions of our Superior Court of Justice, where, for example, Justice Ruy Rosado de Aguiar Júnior, based

\footnotetext{
13 See the already classic work of Konrad HESSE .: "A Força Normativa da Constituição", translated by Gilmar MENDES, Editora Sérgio Fabris, Porto Alegre, 1991.

${ }^{14}$ In "Teoria Geral do Direito Civil", 3rd ed., Coimbra, 1994, p. 75.

15 Identical is the inclination of the Italian courts. See L. MENGONI, . "Autonomia privata $\theta$ Costituzione", in Banca e Borsa, Parte I, 1997, p. 01.
} 
in the German doctrine, fundaments his vote exactly in the Drittwirkung, applying the fundamental rights in the contractual relation. ${ }^{16}$

To the doctrine of the classic International Law, the norms of the treaties prevail upon the national system of law, but this is not guaranteed by any international a rule.

Brazil signed the American Convention of Human Rights, also knew as Pacto de San José de Costa Rica ${ }^{17}$, in 1992, and incorporated to national legislation This Convention forbid the prison for a civil obligation. However, our Constitution admits the prison for a civil obligation in two situations : debts for alimony and for the depositor that does not keep in safe the thing deposited or left lying, as is wrote in his article 5, LXVII.

After the signature of this Convention of Human Rights, a conflict was created in Brazil, because one part of the Doctrine and the Courts said that the Constitution norm could not be changed by the international treaty. This is the position of the Supreme Court of the Nation, STF. The other part of the Doctrine and one Court ${ }^{18}$, said that the constitutional norm, that disposes in a different way of the American Convention of Human Rights, must be changed and it is no more compelling .

Despite this situation, the contract concept in Brazil leads to a conception nearer to that one professed in other Law systems, equally reached by the post-modernism leanings, that place the Human being in the center of the legal system, and, to protect its rights more efficiently, even if in the exercise of the private autonomy, it imposes the respect, by the contracting parties, of the fundamental rights.

Recently, the Supreme Court of the Nation decided against his own jurisprudence and said that the prison for a civil obligation, in this case for alimonies, is no more possible, because the country has signed the Pacto de San José de Costa Rica ${ }^{19}$. Concerning the depositor that not keep the thing in safe, this Court continues to decide against the Convention. But in some State Courts, like São Paulo and Rio Grande do Sul, the justices decide always against the prison for any kind of civil debt ${ }^{20}$.

Although unilateral acts can not hurt the principles of the economic order: private property, social function of property, free competition, defense of consumer, defense of environment, as says Constitutional's article 170.

Having seen one of the forms through which the contract conception in $21^{\text {st }}$ Century starts to acquire international contours, let us examine another base of the international contract conception, the use of the General Principles of Law as law of national contracts.

\footnotetext{
${ }^{16}$ Example of this leaning is the decision number 66/26, published in the STJ (Brazilian Superior Court of Justice) journal. "Agravo Regimental" interposed by the Banco do Brasil, in the instrument number 49.124-2-RS. The distinguished Justice Ruy Rosado de Aguiar Júnior ruled in the following terms: the rules that ensure the fundamental rights of the citizen are established not only to regulate the relations of the citizen with the State, but also to guide all the sphere of the private life, on which they also befall.

17 The Pacto was concluded at 22 November 1969 and 12 countries signed it.

18 The Superior Court of Justice, STJ.

19 This decision was not published.

${ }^{20}$ Recurso APC n 196190383, in 28/11/1 996, Porto Alegre; Habeas Corpus n. 62.192-5, São Paulo, $7^{\text {a }}$.Câmara de Direito Público, in 01.12.97.
} 

Contracts.

Second Part : The General Principles of Law, its application as law of National

The knowledge of the General Principles of Law requires on one hand, a study of Comparative Courts decisions, task that has been always doctrinal incumbency ${ }^{21}$ and, on the other hand, the reference to these Principles in one determined contract, discloses the intention of the parties to deduct its relation from the sphere of a domestic law.

For a long time, the Brazilian Doctrine relates, and the decisions of our Courts uses, the General Principles of Law with the intention to fill the gaps of the law, appealing, therefore, to the Comparative jurisprudence.

Between the objectives we considered to reach, what interests us the most, as already mentioned, is the role of the General Principles of Law as supplier of structural elements of the contract, and the means its application can influence the construction of an international concept of this important legal category.

It is imperative to inquire how the Brazilian Law and the other private orders of Latin America would receptionate this principial form of regulating the contractual relation. country law.

The countries that had been colonized suffer the reception of the colonizer's

In the South American Continent at least two great receptions had occurred. The first one, during the colonial period, when there was almost a juridical unity in the Continent, because the Ordinances of the Kingdom were a common system to the Spanish and Portuguese colonizers.

The second great reception took place after the Independence of the Colonies; having the great majority of the new States opted for the Code Napoléon, due to its prestige and, above all, because it represented a vehicle of the ideas of the Revolution of 1789, which inspired the independence movements in Latin America. This reception did not have the same intensity in the whole Continent, since two of the legislators, the Brazilian and the Chilean, had intended, in the extent they could, to preserve the old Colonial Law, already significantly developed, thanks to the jurisprudence. In our case, as a result of the formation of Teixeira de Freitas, the former drafter of the Brazilian Civil Code, there had been a clear roman influence, revealed by the adoption of a General Part in the Civil Code. ${ }^{22}$

\footnotetext{
${ }^{21}$ We wrote on the subject of the role of the comparative doctrine in the diffusion of the application of the General Principles of Law to supply gaps of the Law in "L'utilisation du droit comparé pair les tribunaux aux Brésil." Rapport au XIVème. Congrès International de Droit Comparé, Athènes 1994, p. 07-General Reporter : M. Ulrich
DROBNIG.

${ }^{22}$ On this matter see our article "A circulação de modelos jurídicos europeus na América Latina, um entrave à integração econômica no Cone Sul? Revista dos Tribunais, vol. 736, 1997, p. 20.
} 
It can be said that a third reception began in the eighties. This reception is a result of the "admission" of Brazil in the International Markets, to a great circulation of contractual legal models of North American origin, through the so-called Business Law.

Moreover, the national doctrine, through some of its exponents, divulged, in books, periodic, congresses and legal nature events, the most up to date solutions of the German and French Laws, exceptionally enriching the specialized national literature, and basing notables decisions of our Courts.

Considering the beginning of the new millennium, the contract notion leads to a gradual disconnection of its typical national parameters, to customize it to this leaning, already cited, of approximating it to the contractual model that circulates in the international spheres.

The contract interpretation itself, in this case a consumer relation, according to a recent decision of the Brazilian Superior Court of Justice, must be made taking the globalization into consideration. ${ }^{23}$

The now praised conception aims, as it was seen, to overcome the divergences between norms and systems of the distinct national codifications, facilitating the international and transnational trade as well as making it more flexible.

On the other hand, as before mentioned, the leaning of projecting the fundamental rights in the private relations between equal contractors, every time that breaches of the personality rights occur, approximate the national contract conception to that dominant in the western legal systems.

\section{CONCLUSION}

The relationship between Constitution, International Treaties and Contracts in Brazil are not well defined, as we could see through the description made above.

The reasons of this can be find in the old tradition of Brazilian system, concerning the relations between national law and international law. When almost every country considers the law of the international treaty as a national law, and any national law that is in conflict with the international rule must be changed, some Brazilian doctrine and Courts continue to regard in the same way they did in the past.

The examples we gave of a new position on this matter, can show that despite all these difficulties, brazilian contract law is changing, in the aim to adopted a contractual conception that is similar to the conception of the others law systems of the occidental world.

\footnotetext{
${ }^{23}$ See RE63981SP, still not published. Its summary follows: "Consumer Law. Defective merchandise acquired in a foreign country. Obligation of the national company of the same mark to repair the damage. Reporter Justice Ruy Rosado de Aguiar Júnior. Product quality defect. Photo cameras bought in Miami. Device presented defect when the buyer was already in Brazil, having the Panasonic company refused to accept the warranty.
} 